\title{
Preventing Tuberculosis in Families of East Timor Expatriate Tuberculosis Patients in Indonesia
}

\section{Sebastianus Kurniadi Tahu* and Yohanes Dion}

Nursing department, Faculty of Health, Citra Bangsa University

\section{ORCID}

Sebastianus Kurniadi Tahu: https://orcid.org/0000-0002-0330-9260

Corresponding Author:

Sebastianus Kurniadi Tahu;

email:

sebastiankurniadi@ymail.com

Published: 7 February 2022

Publishing services provided by

Knowledge E

(c) Sebastianus Kurniadi Tahu and Yohanes Dion. This article is distributed under the terms of the Creative Commons.

Attribution License, which

permits unrestricted use and redistribution provided that the original author and source are credited.

Selection and Peer-review under the responsibility of the IVCN Conference Committee.
Abstract. Tuberculosis is a highly contagious disease caused by rod-shaped bacteria (bacilli) known as Mycobacterium tuberculosis. The housing of East Timor expatriates in Indonesia is very close to each other, with unsanitary environmental conditions and poor ventilation, thus making this community vulnerable to disease transmission, especially of infectious diseases such as pulmonary tuberculosis. This study aimed to examine the attitudes and behaviors associated with preventing tuberculosis in the families of East Timor expatriate tuberculosis patients. This was a descriptive study with a survey and observational approach. The sample consisted of 36 respondents and data were collected using a questionnaire with 27 questions about attitudes and behaviors to prevent TB transmission. The average age of the respondents was 38 years old. $53 \%$ of respondents were male and $42 \%$ graduated from elementary school. The results showed that $69 \%$ had a positive attitude to the prevention of pulmonary TB transmission in the family and $61 \%$ mostly behaved well in their behavior to prevent pulmonary TB transmission. Based on these findings, health workers need to improve health promotion programs with family empowerment methods, as well as advocate for the Government to pay attention to the quality of environmental sanitation and increase the number of patients who recover from TB.

Keywords: tuberculosis, pulmonary, prevention and control

\section{Introduction}

Tuberculosis is one of the easily transmitted diseases caused by rod-shaped bacteria (bacilli) known as Mycobacterium tuberculosis [1]. The initial symptoms of this disease are cough and accompanied by fever which is similar to other diseases, so that people think it is just an ordinary disease and do not want to do a more intensive examination. When the cough does not stop for 2 weeks, it is even accompanied by blood, which indicates the disease is severe, then do the examination and treatment, this lack of understanding can cause pulmonary tuberculosis to spread easily [2]. Since 1999, the community of the East-Timor Exspatriates (Ex Tim-Tim) has chosen to join Indonesia so 
live on the same land in Naibonat - Kupang - East Nusa Tenggara (NTT) - Indonesia. The housing for the Ex Tim-Tim community is also very close together because the houses built by the government are close to each other, the environmental conditions are still not clean and the ventilation of the house is also not good, making the Ex Tim-Tim community vulnerable to disease transmission, especially infectious diseases such as Pulmonary tuberculosis.

The World Health Organization [3] stated that there were 10.4 million people sick with tuberculosis and 1.7 million died from tuberculosis. More than $95 \%$ of deaths from pulmonary tuberculosis occur in low- and middle-income countries. In Indonesia, pulmonary tuberculosis is one of the national priorities for disease control programs because it has a broad impact on the quality of life and the economy, and often results in death. Pulmonary tuberculosis from year to year has increased even though various efforts have been made ranging from counseling to free treatment at health centers and hospitals.

The number of new cases of pulmonary tuberculosis in Indonesia was 420.994 cases in 2017 (data as of May 17, 2018). Based on data from the NTT provincial health office in May 2020, out of 427 health service facilities in NTT, there were 17 health service facilities that had report new data, including in Kupang Distric, a total of 22 cases. Tuberculosis patients at the Naibonat Health Care Center in 2019 totaling 76 people. In 2020 from January to June 2020 is 61 people. Patients with tuberculosis, residents of the ex-Tim-Tim were 33 people. The Hamlet 15 area is an Hamlet inhabited by the community of ex Tim-Tim as many as 144 heads of families or 624 people who are divided into, 307 men and 317 women.

\section{Method}

This research was a descriptive study with a survey and observation approach. The sample in this study was taken based on total sampling on all TB patients ex Tim-Tim in Naibonat - Kupang Regency - East Nusa Tenggara - Indonesia. Population and sample in this research was all patients and their families in Hamlet 15 Naibonat Region, Kupang Regency as many as 36 patients. The inclusion criteria: (a) The patient and one of the family members as decision makers in the family; (b) Patients and family members who are willing to be respondents; (c) Patients and family members who can read, write, communicate well and are cooperative; (d) Patients and family members who are at least 18 years old. Data collection process: starting from getting data on TB patients from the Naibonat health center, then coordinate with the head of the Neighbourhood 
TABLE 1: Characteristics of respondents (n-36)

\begin{tabular}{|c|c|c|}
\hline & Frequency & Precentage (\%) \\
\hline Age, Years (Range, Mean, \pm SD) & & $25-52,38.92, \pm 9.44$ \\
\hline \multicolumn{3}{|l|}{ Gender } \\
\hline Male & 19 & 53 \\
\hline Female & 17 & 47 \\
\hline \multicolumn{3}{|l|}{ Education Level } \\
\hline Elementary School & 15 & 42 \\
\hline Junior High School & 10 & 28 \\
\hline Senior High School & 9 & 25 \\
\hline College & 2 & 5 \\
\hline \multicolumn{3}{|l|}{ Job Status } \\
\hline Housewife & 14 & 39 \\
\hline Farmer & 15 & 42 \\
\hline Private employes & 4 & 11 \\
\hline Government employes & 3 & 8 \\
\hline
\end{tabular}

37 and 38 and then meet with respondents to collect data by asking them to sign the consent form to become a respondent and fill out a questionnaire.

This study uses one variable or single variable, namely: Survey of tuberculosis transmission behavior in families of tuberculosis patients and families of Ex Tim-Tim in the Naibonat Region, Kupang Regency. The study used a questionnaire about attitudes and behaviors to prevent TB transmission with 27 questions (attitudes 14 and behaviors 13) with answers using Likert scale. The answers category used $4=$ strongly agree; $3=$ agree, 2 = disagree and 1 = strongly disagree .

A questionnaire has been tested for validity and reliability with the following values: The attitude questionnaire consists of 14 questions with the results of the test value of $r$ table 0.632 with a Cronbach alpha value of $\geq 0.798$, the questionnaire is declared reliable and the behavioral questionnaire consists of 13 questions obtained a value of 0.444 with a value of Cronbach's alpha $\geq 0.662$ and stated that both questionnaires were reliable.

The research was conducted on June 21 - July 31, 2021 then univariate data analysis was carried out using percentage proportion analysis to get an overview of the variables studied. 
TABLE 2: Characteristics of respondents based on information about pulmonary tuberculosis ( $\mathrm{n}=36$ )

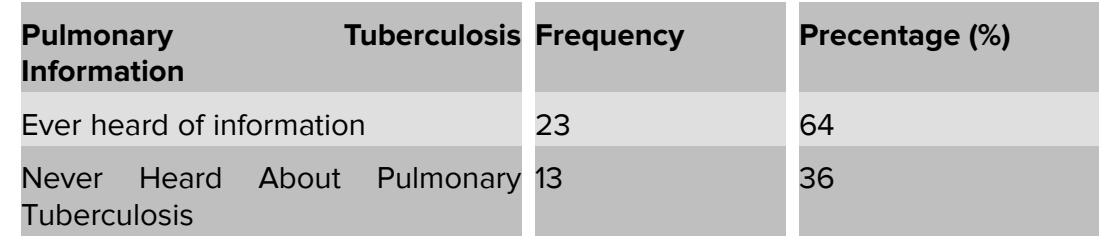

TABLE 3: Characteristics of Respondents by Type of Information ( $n=36)$

\begin{tabular}{|c|c|c|}
\hline Type of Information & Frequency & Precentage (\%) \\
\hline $\begin{array}{l}\text { Health Workers from the Health } \\
\text { Center }\end{array}$ & 11 & 31 \\
\hline Student Counseling & 9 & 25 \\
\hline Social media & 3 & 8 \\
\hline $\begin{array}{l}\text { Never Heard About Pulmonary } \\
\text { Tuberculosis }\end{array}$ & 13 & 36 \\
\hline
\end{tabular}

\section{Result}

Based on table 1, it was found that the average age of the respondents were 38 years old, the youngest were 25 years old and the oldest were 52 years old. The most respondents were male, as many as 19 people (53\%), the most respondents graduated from elementary school (42\%), and it was found that the most respondents worked as Neighbourhood 14 people (39\%) and the least respondents worked as civil servants, namely 3 people (8\%).

Based on table 2, it was found that the most respondents had heard of pulmonary tuberculosis, namely 23 people (64\%).

Based on table 3, it was found that the most of the respondents had never received information on tuberculosis as many as 13 people (36\%) and the least respondents received information about tuberculosis from social media (8\%).

Based on table 4, it was found that the attitude of respondents towards preventing transmission of pulmonary TB in the family was mostly positive as many as 25 people (69\%) while the behavior of preventing transmission of pulmonary TB in the family was mostly good as many as 22 people (61\%).

TABLE 4: Description of attitudes and behavior to prevent transmission of pulmonary tuberculosis in the family $(n=36)$

\begin{tabular}{l|l|l}
$\begin{array}{l}\text { attitudes and behavior to prevent transmission of Frequency } \\
\text { pulmonary tuberculosis }\end{array}$ & Precentage (\%) \\
\hline $\begin{array}{l}\text { Attitudes Positive Negative } \\
\text { Behavior Good Medium Bad }\end{array}$ & 2511 & 6931 \\
\hline
\end{tabular}




\section{Discussion}

Based on the results of the study, the data showed that most of the respondents were in the category of positive attitudes in preventing pulmonary TB transmission in the family and at least the respondents were in the category of negative attitudes. Attitude is still a closed reaction, not an open reaction or open behavior. Attitude is readiness to act on an object in a certain way. Readiness referred to here is a potential tendency to react in a certain way when an individual is faced with a stimulus that requires a response or a tendency to respond (positively or negatively) a person to a particular stimulus or object. Attitude contains an emotional or affective assessment (happy, hate, sad), cognitive (knowledge of an object) and conative (tendency to act) [4].

Attitude is a reaction or response that is still closed from a person to a stimulus or object, the manifestation of that attitude cannot be seen directly, but can be interpreted in advance from closed behavior, and certain regularities in cognitive terms (thinking), affective (feelings) and cognitive (predisposing actions) to an aspect in the surrounding environment [5]. This study was in line with research conducted by [6] based on the results of the study, it was found that most of the respondents were in the category of positive attitudes towards TB disease, while the least respondents had negative attitudes towards TB disease. The results of this study are also in accordance with research conducted by [7] which found that there was a significant relationship between the attitude of the respondents and the incidence of tuberculosis.

Researchers believe that family attitudes are very important in preventing pulmonary TB by: Always paying attention to the bedroom window to be opened every morning so that air and sunlight enter the room, positive pulmonary TB patients always pay attention to good cough etiquette by using a handkerchief when you want to cough so that other people don't get infected with pulmonary TB, then when talking to other people don't get too close to avoid transmitting pulmonary TB, family members who cough continuously for more than 3 weeks should immediately check with the nearest health service and always cleanliness of the living environment in order to affect the spread of pulmonary TB. Early detection and treatment are important determinants of successful pulmonary TB control.

The results of the study show that family attitudes are very important in preventing pulmonary TB, namely by: keeping a distance from other people when talking so as not to transmit as much disease, families understand the spread of TB in a bad living environment, always pay attention to room windows to be opened every morning so that there is a change of air and sunlight entering the room, positive pulmonary TB patients 
should not throw phlegm anywhere, positive pulmonary TB patients do not need to have their own eating utensils, families understand that herbal medicine cannot prevent TB, and TB patients do not have to be ostracized from their family and friends. society and its work.

The attitude of patients and their families is positive because the majority of respondents have often heard information about TB from health workers, consultants and social media. TB information obtained can increase the knowledge of sufferers and their families which can influence their attitudes for the better. Families or patients should participate more in health education activities in order to improve pulmonary TB prevention behavior. The results of the study also showed that the age factor affected changes in individual attitudes, the average productive age so that they could change the attitudes or behavior of family members about improving health in the family towards preventing transmission of pulmonary TB in the family. Education of most respondents is in the high school category.

The researcher's opinion is that high school education affects the respondent's mindset, because in high school education his thinking ability is still in a concrete form so that it affects a person's ability to view an object about preventing pulmonary tuberculosis transmission in the family. So that families know how to deal with if someone has pulmonary TB and the family knows that pulmonary TB disease can be contagious, therefore it is expected that families pay more attention to the cleanliness of the surrounding environment in order to prevent the increase in pulmonary TB patients in the family.

Based on the results of the study, it was found that the family behavior was the most respondents who had good behavior about preventing the spread of pulmonary TB in the family and the least respondents who had poor behavior. Behavior is a person's response or reaction to a stimulus (stimulus from outside). Thus human behavior occurs because of the process: Stimulus-Organism-Response, so Skinner's theory is called "S-O-R" [4]. Based on the "S-O-R" theory, human behavior can be grouped into two, namely: Cover behavior. Closed behavior occurs when the response to the stimulus is still not clearly observed by others (from outside). A person's response is still limited in the form of attention, feelings, perceptions, knowledge and attitudes towards the relevant stimulus. This open behavior occurs when the response to the stimulus is already in the form of an action or practice that can be observed by others from outside. According to [4], Behavioral factors are formed within a person from two main factors, namely: (External factors) Factors from outside a person's stimulus is a factor of the physical environment, and non-physical in the form of socio-cultural, 
economic, political and so on (Internal factors). Factors from within a person, which determine a person's response to external stimuli are attention, observation, perception, motivation, fantasy, suggestion, and so on that influence the formation of behavior such as attention, motivation, intelligence, fantasy, and so on, as mentioned above, covered by psychology.

According to [9], the classification of Health Behavior, namely: Health-care behavior is a person's effort to maintain or maintain health so as not to get sick and healing efforts when sick. Behavior seeking or using a health system or facility, or often called treatment seeking behavior. This behavior is related to whether or not a person's efforts when suffering from illness or accident. Environmental health behavior is when a person responds to the environment, both physical and socio-cultural environments and so on.

Research by [10] shows that there is a good relationship between good behavior and prevention of respondents' TB. A person's behavior that is lacking can be caused by a lack of firm attitude and lack of motivation. Transmission of TB disease will easily occur among residents of the house, because the house is too narrow so that the transmission of germs from one human to another will more easily occur. That the patient's behavior can be influenced not only because of educational factors, but also because of the motivation to recover [11].

The behavior of preventing tuberculosis transmission can be influenced by age. The results showed that most of the respondents were in the early adult age group. [12], revealed that age affects a person's cognitive development and insight is an aspect that determines a person's behavior regarding the prevention of pulmonary TB transmission. The maturity level of families with pulmonary tuberculosis synergizes with the development of a person's age, where age forms the experience of early adult groups who have broader experience related to how to prevent the transmission of pulmonary tuberculosis. This is caused by the development of thinking patterns, where the development of this mindset affects insight so as to form actions to prevent the transmission of pulmonary tuberculosis. Actions taken are to maintain health, motivate families suffering from pulmonary tuberculosis to take treatment. Housewife is a mother figure who plays a role in taking care of the household, nurturing and educating children, meeting the affective and social needs of her family [13]. According to the researcher, housewives have the responsibility and obligation to pay attention to the health of their home, environment and family health when they are sick, a mother will automatically take care of sick family members and bring them to the health service, as well as provide nutritious food for their families and adequate rest so that the system can function properly. 
The results showed that most of the respondents had good behavior towards the prevention of pulmonary tuberculosis transmission in the family. Basically one of the factors that influence behavior is attitude. People's attitudes about tuberculosis can encourage people to take steps to prevent transmission because they know the dangers of tuberculosis. Families or patients should participate more in health education activities in order to improve pulmonary TB prevention behavior. The results also show that the age factor affects changes in individual attitudes, the average productive age so that it can change the attitude or behavior of family members about improving health in the family towards preventing pulmonary TB transmission in the family, and the opinion of researchers about education where most of the respondents are in the high school category. Education plays a role in improving one's mindset and insight, the higher the education the better one's knowledge. [8], people's attitudes about domains are very important in shaping one's behavior. This is caused by the attitude factor owned by the respondent. The results of the research on attitudes showed that most of the respondents had a positive attitude towards the prevention of tuberculosis so that the preventive behavior carried out by the respondents was good. This study also explains that the family plays an important role in all levels of disease prevention.

Transmission prevention behavior in families of tuberculosis sufferers in this study showed that most of the respondents took good actions such as the family already knowing the right actions when coughing or sneezing by covering their mouths using handkerchiefs, wearing masks when talking to other people, while getting medicine from family doctors. drinking regularly as recommended by doctors and family, don't forget to dry the mattress and pillows that have been used.

\section{Conclusion}

The attitude and behavior prevention toward the spread of tuberculosis of the EastTimorese community were categorized as a good level. Based on this finding, health workers need to improve health promotion programs with family empowerment methods as well as advocate for the government to pay attention to the quality of environmental sanitation and increase the number of patients who recover.

\section{Acknowledgment}

We are gratefull to Regent, Village Head, and head of the East-Timorese Community in Naibonat for their support and help during data collection. 


\section{References}

[1] World Health Organization. TB burden report. Geneva: World Health Organization; 2018. Available from: https://apps.who.int/iris/handle/10665/274453

[2] Iwan, I., Dalle, A., Heriansyah, H., \& Pashar, I.. Gambaran motivasi keluarga dalam pencegahan penularan tuberkulosis paru di rumah sakit umum daerah sinjai description. 2019;10:25-31.

[3] WHO. Be Po. Eur Respir J. 2014;44(1):23-63.

[4] Notoatmodjo S. Promosi kesehatan dan perilaku kesehatan. Jakarta: Rineka Cipta; 2014.

[5] Wawan A, Dewi M. Teori dan pengukuran pengetahuan, sikap, dan perilaku manusia. Teori dan pengukuran pengetahuan, sikap, dan perilaku manusia. Nuha Medika: Yogyarkarta.2016.

[6] Djannah SN, Suryani D, Purwati DA. Hubungan tingkat pengetahuan dan sikap dengan perilaku pencegahan penularan tbc pada mahasiswa di asrama manokwari sleman Yogyakarta. Jurnal Kesehatan Masyarakat ( Journal of Public Health). 2014;3.

[7] El Kharisma, Hubungan Pengetahuan Dan Faktor Risiko Dengan Kejadian TB Paru BTA (+) Di Wilayah Kerja Puskesmas Padang Pasir Tahun 2017. 2017

[8] Azwar S. Sikap manusia: Teori dan pengukurannya. Yogyakarta: Pustaka Pelajar; 2013.

[9] Waryana, W. Promosi kesehatan, penyuluhan, dan pemberdayaan masyarakat: Untuk dosen, mahasiswa, bidan, perawat, tenaga kesehatan, dan umum. Yogyakarta: Nuha Medika; 2016.

[10] Lusiawati E. Hubungan pengetahuan pasien TBC dengan perilaku pencegahan penularan kepada keluarga di puskesmas sienjo. IImu Keperawatan. 2016;4:10310.

[11] Priyoto P, Anisia D, Hartono A, Pitayanti A. Perilaku kesehatan dan pendidikan kesehatan. Yogyakarta: Pustaka Panasea; 2018.

[12] Mubarak WI, Chayatin N. Ilmu kesehatan masyarakat: Teori dan aplikasi. Jakarta: Salemba Medika; 2011.

[13] Dion Y, Betan Y. Asuhan Keperawatan keluarga: Konsep dan praktik. Yogyakarta: Nuha Medika; 2013.

[14] Muslim HM. Parasitologi untuk keperawatan. 2009. Available from: https://www.mendeley.com/profiles/violla-anggiani/. EGC : Jakarta 